\title{
Karakteristik Third Place dan Tipologi Kafe di Yogyakarta Kasus: Kawasan Karangwuni dan Sekitarnya
}

\author{
Third Place Characteristics and Typology of Café in Yogyakarta
}

Case: Karangwuni Sub-district and the Areas Nearby

\section{Talenta Nanda Sireki ${ }^{1}$ dan Bambang Hari Wibisono ${ }^{1}$}

\author{
Diterima: 1 Agustus 2019 Disetujui: 2 April 2020
}

\begin{abstract}
Abstrak: Perkembangan teknologi dapat menyebabkan terjadinya pergeseran bentuk interaksi dan aktivitas yang dilakukan di dalam third place, sehingga dapat merubah karakteristik third place. Penelitian ini bertujuan untuk menunjukkan karakteristik kafe sebagai third place, tipologi dan perkembangan spasial, serta mengidentifikasi faktor pembentuk tipologi pada kafe sebagai third place di Kawasan Karangwuni dan sekitarnya (Karangwuni, Karanggayam, Karangasem Baru, Karangbendo, dan Karangmalang). Penelitian ini menggunakan metode mix-method dengan pendekatan deduktif-eksploratif yang dilakukan melalui survei lapangan dan kuesioner terhadap pengunjung pada kafe sebagai third place yang dibuka antara tahun 2016-2018 dan berlokasi di Kawasan Karangwuni dan sekitarnya. Hasil dari penelitian ini menunjukkan bahwa karakteristik third place pada kafe di Kawasan Karangwuni dan sekitarnya masih sesuai dengan karakteristik yang dikemukakan oleh Oldenburg. Namun demikian, ditunjukkan pula mulai terjadinya pergeseran bentuk interaksi dan aktivitas yang dilakukan. Analisis tipologi yang dilakukan menunjukkan adanya beberapa tipe kafe yang sesuai dengan bentuk penggunaan co-working space dan terdapat kecenderungan spasial dalam tipologi berdasarkan aktivitas. Adapun beberapa faktor pembentuk tipologi memiliki hubungan dengan setting ruang dalam mendukung perilaku penggunanya.
\end{abstract}

Kata kunci: third place, kafe, aktivitas, interaksi, tipologi

\begin{abstract}
Technology advancements tend to trigger the transformation of the characteristics of third place, especially in the forms of interactions and activities. This research is aimed to explore the third place characteristics, typology, spatial development, and identify factors that construct the typology of cafés as third place in Karangwuni sub-district and the area nearby (Karangwuni, Karanggayam, Karangasem Baru, Karangbendo, dan Karangmalang). The research method used in this study was a mix-method, with deductive-explorative approach using field observation and questionnaire to the visitor of café as a third place, which were opened during the period between 2016 to 2018, and located in Karangwuni area and the areas nearby. The results of this study shows that the characteristics of cafés in Karangwuni and the areas nearby as a third place are still in accordance with Oldenburg's characteristics. However, it is also revealed that there have been shifts of the form of interactions and activities within the cafés space. Typology analysis showed that there are several types of cafés that match with the form of co-working space, and there are spatial trends in typology based on activity. Meanwhile, some factors constructing the typology have relation with space settings in determining the behaviors of the users.
\end{abstract}

Keyword: third place, café, activity, interaction, typology

\footnotetext{
${ }^{1}$ Departemen Teknik Arsitektur dan Perencanaan, Fakultas Teknik, Universitas Gadjah Mada
} 


\section{PENDAHULUAN}

Ruang merupakan tempat hidup dan berkegiatan manusia. Kombinasi dasar sebuah ruang adalah keberadaan manusia, tempat, dan aktivitas di dalamnya. Masing-masing komponen tersebut saling mempengaruhi pembentukan persepsi manusia tentang ruang sesuai dengan karakteristik elemen pembentuk. Ruang dapat diklasifikasikan menjadi tiga kategori yang dibedakan berdasarkan kegiatan pokok di dalamnya. Pada awalnya, ruang hanya diklasifikasikan menjadi dua kategori, yakni first place dan second place sesuai dengan aktivitas yang berlangsung dalam penggunaannya. First place didefinisikan sebagai ruang untuk beristirahat, sedangkan second place didefinisikan sebagai ruang untuk bekerja (Oldenburg, 1989). Perkembangan kegiatan kehidupan manusia sehari-hari turut memicu perkembangan ruang yang ada menjadi tiga kategori, salah satu pemicunya yakni adanya kebutuhan manusia akan ruang in-between, dari kehidupan formal keseharian, dengan sifat informal yang memberi kebebasan sosial bagi manusia di dalamnya.

Third place didefinisikan sebagai ruang untuk berinteraksi, sosialisasi, atau tempat berkumpul selain tempat beristirahat dan tempat bekerja yang dapat sering didatangi (Mehta dan Bosson, 2010). Orang-orang yang mendatangi third place memanfaatkan ruang ini sebagai tempat untuk menghilangkan stres, dan mengalihkan rasa kesepian serta keterasingan. Teori third place pertama kali dikemukakan dalam buku The Great Good Place (Oldenburg, 1989). Keberadaan third place dinilai penting dalam memberikan wadah bagi manusia untuk menjadi retensi atas rasa jenuh terhadap aktivitas hidup yang dilakukan setiap hari, dan menjadi media bagi manusia dalam memenuhi kebutuhan sosial dengan sifat informal. Ruang-ruang yang dapat memenuhi karakteristik third place biasanya berbentuk ruang kafe, bar, restoran, atau bentuk lain yang bersifat lebih informal.

Interaksi antar-manusia seiring berjalannya waktu turut berinovasi, salah satunya disebabkan karena perkembangan teknologi. Teknologi mampu menghilangkan batasan (jarak dan waktu) yang menjadi hambatan antar-manusia dalam berinteraksi. Perkembangan teknologi berpengaruh banyak dalam bentuk interaksi manusia, seperti mengubah pola interaksi sehari-hari manusia. Fenomena tersebut berpengaruh pula bagi third place, khususnya pada karakteristik third place (interaksi merupakan hal utama). Teknologi mampu mengubah ruang yang semula ditujukan untuk berinteraksi secara langsung, menjadi ruang berinteraksi secara tidak langsung (melalui media teknologi dan media sosial). Perkembangan teknologi ini mampu mengubah karakteristik third place yang dikemukakan oleh Oldenburg (Pozos-Brewer, 2015).

Berkembangnya Internet of Things (IoT) mampu memudahkan kehidupan manusia di berbagai sektor dengan digitalisasi. Sebagai contoh adalah kemudahan dalam bekerja yang saat ini dapat dilakukan dari jarak jauh (remote), dalam artian pekerja tidak perlu berada di kantor untuk melakukan pekerjaannya (Nenonen \& Kojo, 2016). Hal ini memicu perkembangan third place menjadi bentuk ruang co-working space yang merupakan kombinasi ruang informal (sosial) dan formal (produktif, fungsional), sehingga dalam melakukan pekerjaan pengguna ruang dapat berinteraksi dan berkolaborasi dengan orang lain (Brown, 2017).

Kafe sebagai salah satu wadah berinteraksi informal atau third place di Yogyakarta mengalami peningkatan kuantitas yang pesat beberapa tahun belakangan ini. Kondisi tersebut dipengaruhi oleh keberadaan kaum urban di Yogyakarta. Predikatnya sebagai kota pelajar mampu menarik mahasiswa dari berbagai daerah (dalam jumlah besar) untuk bermukim di Yogyakarta. Salah satu kawasan dengan perkembangan jumlah kafe cukup pesat adalah Kawasan Karangwuni dan sekitarnya (termasuk di dalamnya Karanggayam, Karangasem Baru, Karangbendo, dan Karangmalang - untuk selanjutnya disebut sebagai Kawasan Karangwuni dan sekitarnya). Kawasan ini terletak di antara dua universitas ternama di Yogyakarta, yakni Universitas Gadjah Mada dan Universitas Negeri Yogyakarta. Kawasan ini strategis bagi perkembangan dunia komersial dengan segmen pasar potensialnya adalah mahasiswa. 
Perkembangan teknologi dalam interaksi manusia dan berkembangnya co-working space, mampu mengubah karakteristik (bahkan bentuk third place) kafe di Kawasan Karangwuni dan sekitarnya. Selain itu, peningkatan kuantitas kafe di Kawasan Karangwuni dan sekitarnya menciptakan sebaran spasial dengan pertumbuhan sesuai dengan garis waktu. Kafe yang berkembang memiliki beragam karakter pembentukan masing-masing, baik dari aktivitas yang terbentuk maupun karakter pengunjung kafe, sehingga mampu menciptakan beberapa tipe (tipologi) kafe. Tipologi terbentuk oleh faktor yang tercipta melalui latar belakang atau alasan-alasan pengunjung saat melakukan kunjungan ke kafe (dari sini hadir beragam tipe kafe).

Penelitian serupa pada beberapa penelitian terdahulu memiliki fokus, lokus, dan metode penelitian yang berbeda dengan penelitian ini. Beberapa penelitian terdahulu diantaranya berjudul Pemanfaatan Ruang untuk Waktu Luang di Kalangan Mahasiswa Universitas Gadjah Mada (Fatmawati, 2015) yang berfokus pada analisis pola pemanfaatan waktu luang dan ruang-ruang yang digunakan di kalangan mahasiswa Universitas Gadjah Mada, yang menggunakan metode induktif-kualitatif dan penelitian berjudul Karakteristik Kafe di Perkotaan Yogyakarta, Studi Kasus Kawasan Seturan, Demangan, dan Prawirotaman (Anggrianita, 2016) yang berfokus pada analisis karakteristik pembentukan kafe di perkotaan Yogyakarta dan faktor yang mempengaruhi karakteristik pembentukan kafe tersebut, dengan metode penelitian deduktif-kualitatif. Penelitian ini akan berfokus untuk mengidentifikasi dan memahami karakteristik third place dan tipologi ruang pada kafe di Yogyakarta dengan studi kasus di Kawasan Karangwuni dan sekitarnya dengan menggunakan metode deduktif-mix method yang mengkombinasikan metode kualitatif dan kuantitatif.

Karakteristik berdasarkan Kamus Besar Bahasa Indonesia didefinisikan sebagai sifat khas sesuai dengan perwatakan tertentu, atau sifat khas dari barang atau orang yang dapat menjadi pembeda satu sama lain. Adapun tipologi didefinisikan sebagai pemilahan kelompok objek berdasarkan kesamaan sifat (karakteristik) yang dimiliki (Francis D.K Ching, 1979 dalam Suharjanto, 2017).

Kafe berdasarkan KBBI didefinisikan sebagai tempat minum kopi yang pengunjungnya dihibur dengan musik, atau merupakan sebuah kedai kopi. Secara lebih makro, kafe didefinisikan sebagai tempat memesan makanan ringan dan minuman, dengan tujuan untuk berinteraksi dengan orang lain di ruang publik. Ciri lain kafe adalah tempat ini buka hingga larut malam sehingga jangka waktu untuk berkumpul dan berinteraksi dengan orang lain lebih lama (Fauzi et al., 2017).

Third place didefiniskan sebagai ruang yang sering didatangi untuk berinteraksi secara informal (Oldenburg, 1989). Oldenburg mengidentifikasi karakteristik third place menjadi 8 karakteristik, yakni: merupakan ruang netral; tempat menyamaratakan; interaksi sebagai kegiatan utama; aksesibilitas dan akomodasi fleksibel; adanya pengunjung reguler yang mempengaruhi ruang sosial; a low profile; suasana dinamis; dan a home away from home. Pozos-Brewer (2015) menyatakan bahwa konsep third place yang dikemukakan oleh Oldenburg tidak bersifat umum dan tidak dapat mengikuti perkembangan zaman. Perubahan yang dialami berhubungan pula dengan karakteristiknya yang dirumuskan sebagai berikut: third place tidak bersifat netral (terdapat peraturan dari pemilik kafe, serta dinamika dan hierarki sosial didalamnya); third place tidak ditujukan sebagai tempat berinteraksi (orang yang berinteraksi cenderung menciptakan ruang privat atau berkelompok); perkembangan teknologi merubah kebutuhan interaksi secara langsung dalam third place; pengunjung reguler tidak berkontribusi banyak dalam pembentukan ruang sosial; serta pemilik kafe cenderung menciptakan pengaturan ruang beragam untuk menciptakan suasana ruang sesuai dengan target pasar yang dituju. Third place dapat pula berkembang menjadi co-working space yang merupakan kombinasi antara ruang informal (sosial) dan ruang formal (produktif, fungsional) sehingga dapat menciptakan ruang bekerja dan berinteraksi (Brown, 2017). 
Konsep third place seiring berjalannya waktu turut berkembang mengikuti kebutuhan ruang aktivitas bekerja di tengah pemanfaatan ruang untuk berinteraksi. Konsep ini disebut co-working space yang mengombinasikan ruang informal (sosial) dengan ruang formal (produktif, fungsional) dan menciptakan ruang semi-publik (Brown, 2017). Co-working space muncul guna menyediakan ruang fisik, sehingga masyarakat dapat melakukan pekerjaan di dalamnya sembari melakukan interaksi dengan orang lain (berbagi pekerjaan, berbagi pengetahuan, kolaborasi, dan hal-hal lain) yang berkaitan dengan berbagi ruang untuk aktivitas yang dapat dinilai menghasilkan (Clifton \& Crick, 2016; Merkel, 2015). Dengan kata lain, co-working space merupakan ruang yang dapat digunakan secara bersama-sama, tidak hanya untuk melakukan aktivitas bekerja, namun juga merupakan ruang untuk berinteraksi, sehingga ruang yang tercipta menjadi lebih informal dan tidak menekan. Coworking bukan hanya sekadar berkaitan dengan ruang fisik, melainkan menyangkut pola pemikiran dari pelaku co-working dalam berbagi mengenai apa yang dikerjakan dan cara mereka bekerja (Stumpf, 2013). Kwiatkowski dan Buczynski (2011) dalam Stumpf (2013) mengemukakan bahwa terdapat enam nilai dari co-working space diantaranya yakni komunitas, aksesibilitas, kolaborasi, komunikasi, keterbukaan, dan kreativitas.

Kegiatan waktu luang didefinisikan sebagai penggunaan waktu kosong untuk beraktivitas di luar dari kegiatan rutin sehari-hari, merupakan salah satu komponen utama dalam menciptakan gaya hidup sehat. Passmore dan French (2001) membagi tipologi kegiatan waktu luang bagi remaja menjadi tiga tipe yakni waktu luang untuk prestasi (hobi dan seni kreatif), waktu luang untuk aktivitas sosial (rekreasi dan sosialisasi), dan waktu luang untuk menghabiskan waktu.

Sistem aktivitas didefiniskan sebagai pola perilaku individu, keluarga, institusi, maupun perusahaan yang terjadi dalam pola keruangan serta memiliki makna dalam perencanaan guna lahan (Chapin, 1965). Sistem aktivitas mempelajari interaksi yang terjadi antar-komponen, misalnya analisis dalam pola pergerakan untuk perencanaan transportasi. Dalam penelitian ini, digunakan tipologi sistem aktivitas bagi rumah tangga dan individu yang terbagi menjadi 9 tipe sistem aktivitas, yakni: aktivitas pendapatan dan produktivitas; aktivitas pembinaan keluarga; aktivitas edukasi; aktivitas spiritual; aktivitas sosial; rekreasi dan relaksasi; aktivitas kelompok; aktivitas politik dan komunitas sosial; serta aktivitas konsumtif.

\section{METODE}

Penelitian ini menggunakan metode mix-method dengan pendekatan deduktifeksploratif. Metode mix-method merupakan kombinasi dari metode kuantitatif dan metode kualitatif, sedangkan pendekatan deduktif merupakan pendekatan yang mengambil langkah penelitian dimulai dari konsep kemudian dispesifikasi untuk mendapatkan hasil yang ingin diungkapkan. Dalam metode deduktif, peneliti menganalisis dan menyimpulkan penelitian sesuai dengan teori yang sudah disampaikan pada bagian sebelumnya (Yusuf, 2016).

Unit amatan dalam penelitian ini adalah kafe dengan ruang bersifat third place yang berlokasi di Kawasan Karangwuni dan sekitarnya (Karangwuni, Karanggayam, Karangbendo, Karangasem Baru, Karangmalang) yang mulai dibuka antara tahun 20162018. Pemilihan lokasi dan kafe amatan didasari oleh lokasi yang strategis karena berada di antara kampus UGM dan UNY. Rentang tahun penelitian didasarkan oleh tren pengisian kuesioner awal oleh 265 responden yang menunjukkan bahwa penggunaan kafe terakumulasi pada rentang tahun 2016-2018. 


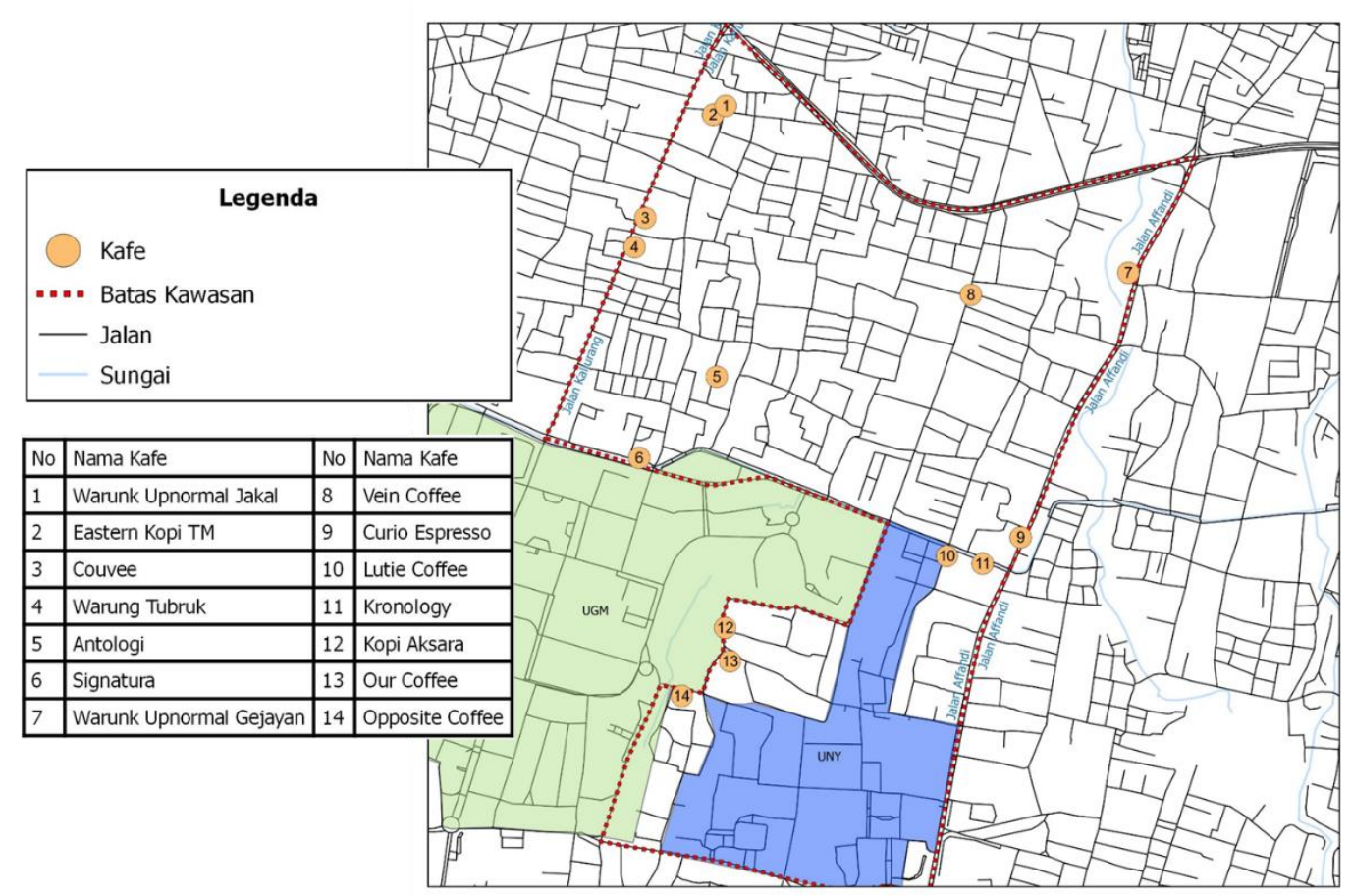

Sumber: Olahan Peneliti, 2019

Gambar 1. Peta Persebaran Kafe yang Diteliti

Unit analisis terbagi menjadi 3 bagian yakni karakteristik third place pada kafe dengan variabel pengalaman pengunjung terkait karakteristik kafe sebagai third place; tipologi dan perkembangan spasial dengan variabel tipologi berdasarkan aktivitas, tipologi berdasarkan karakteristik pengunjung, keterkaitan tipologi dengan lokasi spasial, dan perkembangan spasial; serta faktor pembentuk tipologi dengan variabel latar belakang kunjungan dari pengunjung kafe.

Pengumpulan data dilakukan melalui survei lapangan, penggunaan kuesioner, dan pengumpulan data sekunder. Survei lapangan dalam bentuk observasi digunakan untuk mengetahui lokasi spasial kafe dan melihat karakteristik fisik atau fasilitas dari kafe. Kuesioner disusun dan didistribusikan menggunakan Google Form untuk mendapatkan data dari responden pengunjung kafe. Sedangkan data sekunder yang diambil dari internet digunakan untuk melengkapi hasil analisis yang dilakukan, misalnya kelengkapan shapefile peta.

Sampel dalam penelitian menggunakan metode convenience sampling dengan kriteria yakni orang yang pernah mengunjungi kafe sebagai third place di kawasan Karangwuni dan sekitarnya. Didapatkan 265 responden awal dari kuesioenr untuk melihat akumulasi tren penggunaan kafe, dan kemudian didapatkan 248 responden untuk kafe yang diamati dalam penelitian ini yakni antara tahun 2016-2018.

Dalam penelitian ini, data yang dianalisis berasal dari kuesioner yakni respon dari pengunjung kafe terhadap beberapa pertanyaan terkait variabel penelitian. Data yang terkumpul dianalisis menggunakan Microsoft Excel dan SPSS untuk melihat kecenderungan berdasarkan analisis grafik dan analisis crosstab sehingga dapat disimpulkan menjadi karakteristik dan dirumuskan menjadi tipologi. Analisis lanjutan dilakukan dengan mencari keterhubungan antar hasil analisis sehingga dapat membandingkan antara temuan lapangan dengan teori yang ada. Hasil penelitian ini adalah hasil analisis secara kuantitatif dan kualitatif dengan melakukan perbandingan antara teori perkembangan third place, khususnya kafe, dengan temuan lapangan sehingga dapat diketahui fenomena yang terjadi di lapangan serta fenomena secara spasial. 


\section{HASIL DAN PEMBAHASAN}

Responden dari kuesioner sejumlah 248 orang, masing-masing memiliki pengalaman yang berbeda pada karakteristik kafe yang mempengaruhi keberadaannya sebagai third place. Kecenderungan pengalaman yang dirasakan pengunjung dapat diterjemahkan sebagai kriteria third place pada kafe di Kawasan Karangwuni dan sekitarnya.

Kuesioner disusun dalam 5 pernyataan karakteristik third place yang kemudian dinyatakan dalam persepsi pengalaman pengunjung terkait karakteristik kafe sebagai third place. Karakteristik dalam pernyataan tersebut dirumuskan untuk dapat melihat kecenderungan keseuaian karakteristik sesuai dengan teori awal Oldenburg atau terjadi pergeseran sesuai dengan pernyataan Pozos-Brewer, yakni: ruang informal, peraturan dari pemilik kafe, interaksi dalam kafe, pengunjung reguler dalam penciptaan suasana kafe, pengaturan ruang kafe, dan a home away from home. Data yang diperoleh dapat dilihat pada Gambar 2.

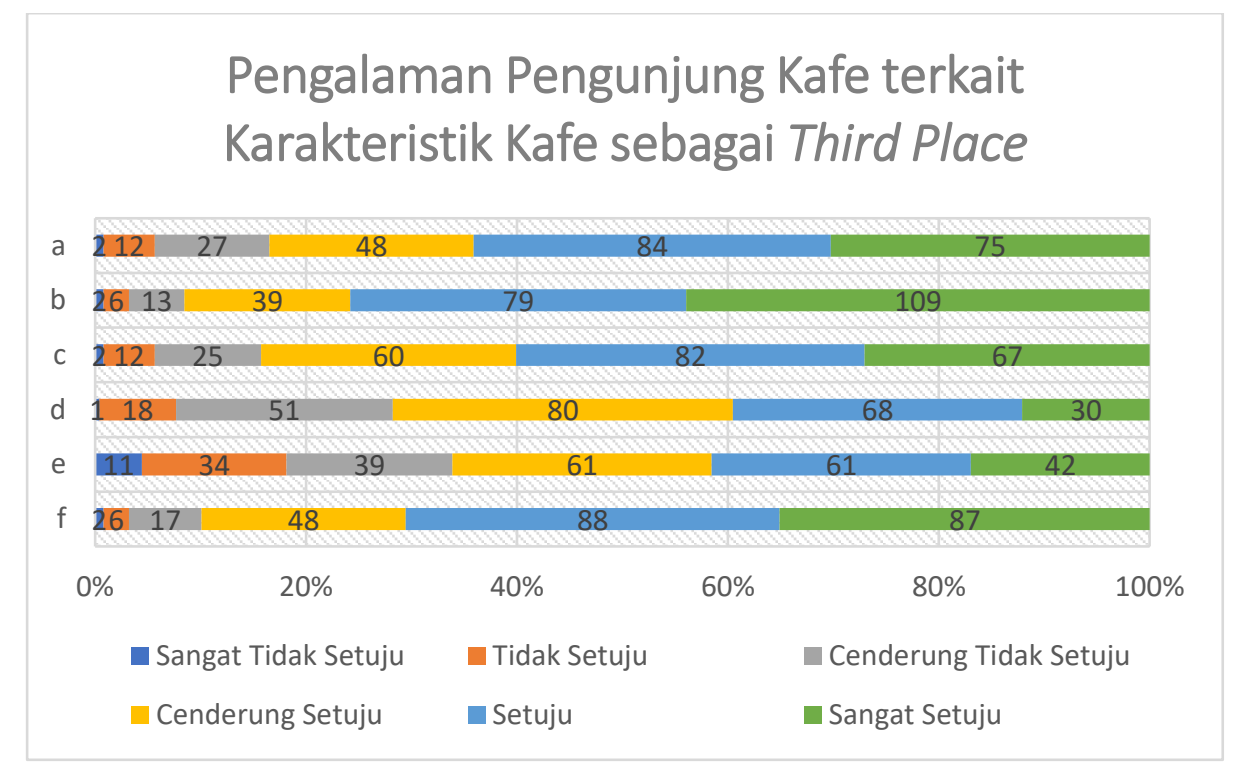

Sumber: Olahan Peneliti Berdasarkan Kuesioner, 2019

Gambar 2. Grafik Pengalaman Pengunjung terkait Karakteristik Kafe sebagai Third Place

\section{Keterangan:}

(a) Kafe merupakan ruang informal.

(b) Tidak ada peraturan mengikat dari pemilik kafe.

(c) Interaksi merupakan kegiatan utama dalam kafe.

(d) Ada pengunjung reguler yang menciptakan suasana pada kafe.

(e) Tidak ada pengaturan ruang dari masing-masing kafe.

(f) Kafe dapat menjadi a home away from home.

Grafik dianalisis sesuai dengan kecenderungan jawaban dari responden kuesioner. Jawaban antara cenderung tidak setuju hingga sangat tidak setuju merepresentasikan karakteristik yang diungkapkan Pozos-Brewer, sedangkan jawaban antara cenderung setuju hingga sangat setuju merepresentasikan karakteristik yang diungkapkan oleh Oldenburg. Hasil analisis grafik pada Gambar 2 menunjukkan kecenderungan responden memiliki pengalaman terkait karakteristik kafe sebagai third place antara cenderung setuju hingga sangat setuju. Hal ini berarti bahwa karakteristik kafe sebagai third place di kawasan Karangwuni dan sekitarnya masih sesuai dengan karakteristik third place yang diungkapkan oleh Oldenburg (1989). Namun pada bagian interaksi yang dilakukan dalam kafe, sudah 
mulai terjadi pergeseran, yang dapat dilihat dari hasil analisis terkait bentuk interaksi pada Gambar 3.

\section{Pengalaman 'Bentuk Interaksi pada Kafe'}

\section{Gambar 3. Grafik Pengalaman Pengunjung terkait Bentuk Interaksi dalam Kafe}

Data yang didapatkan dari kuesioner sejumlah 248 responden dapat dilihat pada Gambar 3, dengan 126 responden atau sebanyak 51,2\% menyatakan kegiatan interaksi langsung merupakan kegiatan yang biasa dilakukan di kafe. Sebanyak $122(49,8 \%)$ responden menyatakan kegiatan interaksi secara tidak langsung (melalui media sosial) merupakan kegiatan yang biasa dilakukan pada kafe. Hal ini menunjukkan bahwa interaksi langsung merupakan kegiatan yang dominan dilakukan pada kafe sebagai third place, meskipun sudah mulai terjadi pergeseran pada bentuk interaksi yang terjadi di dalam kafe sebagai third place. Hasil analisis ini menunjukan bahwa kecenderungan yang terjadi terkait bentuk interaksi sudah mulai bergeser dari interaksi secara langsung menjadi interaksi secara tidak langsung. Pergeseran ini, dipicu oleh penggunaan teknologi dalam interaksi manusia yang dapat menghilangkan batasan jarak dan waktu dalam interaksi.

Analisis crosstab yang dilakukan pada bagian tipologi kafe berdasarkan aktivitas menunjukan kecenderungan masing-masing sub-variabel tiap kafe yang kemudian diterjemahkan sebagai karakteristik tiap kafe berdasarkan aktivitas dalam Tabel 1.

Hasil dari analisis karakteristik tiap kafe menunjukkan bahwa terdapat pergeseran penggunaan ruang kafe sebagai third place berdasarkan sistem aktivitas yang dilakukan di dalam kafe. Sistem aktivitas edukasi merupakan sistem yang mendominasi dilakukan pada kafe yang berada di Kawasan Karangwuni dan sekitarnya. Hal ini menunjukkan bahwa sudah mulai terjadi pergeseran sistem aktivitas yang seharusnya dilakukan pada kafe sebagai third place, yakni dari aktivitas sosial menjadi aktivitas edukasi dengan sifat yang lebih formal kaitannya dengan pendidikan. Kombinasi yang terjadi antara ruang informal dan ruang formal pada kafe sebagai third place dapat menandakan adanya pergeseran bentuk ruang third place menjadi co-working space. Karakteristik yang terbentuk kemudian dibandingkan dan diterjemahkan menjadi tipe dalam tipologi berdasarkan aktivitas pada Tabel 2. 
Tabel 1. Karakteristik Berdasarkan Aktivitas Tiap Kafe

\begin{tabular}{|c|c|c|c|c|c|c|c|c|c|}
\hline \multirow[t]{2}{*}{ Kafe } & \multicolumn{2}{|c|}{ Sistem Aktivitas } & \multicolumn{2}{|l|}{ Tujuan } & \multicolumn{2}{|c|}{$\begin{array}{l}\text { Durasi } \\
\text { Kunjungan }\end{array}$} & \multicolumn{2}{|c|}{$\begin{array}{l}\text { Preferensi } \\
\text { Kunjungan }\end{array}$} & \multirow{2}{*}{$\begin{array}{l}\text { Waktu } \\
21.00- \\
24.00\end{array}$} \\
\hline & Edukasi & $\begin{array}{l}\text { Aktivitas } \\
\text { Sosial }\end{array}$ & $\begin{array}{l}\text { Tujuan } \\
\text { Utama }\end{array}$ & $\begin{array}{l}\text { In- } \\
\text { between }\end{array}$ & $\begin{array}{l}1-2 \\
\text { jam }\end{array}$ & $\begin{array}{l}3-4 \\
\text { jam }\end{array}$ & $\begin{array}{l}16.00- \\
18.00\end{array}$ & $\begin{array}{l}18.00- \\
21.00\end{array}$ & \\
\hline Antologi & $\checkmark$ & & & $\checkmark$ & & $\checkmark$ & & $\checkmark$ & \\
\hline Couvee & $\checkmark$ & & & $\checkmark$ & & $\checkmark$ & & $\checkmark$ & \\
\hline $\begin{array}{l}\text { Curio } \\
\text { Espresso }\end{array}$ & $\checkmark$ & & $\checkmark$ & & $\checkmark$ & & & & $\checkmark$ \\
\hline & $\checkmark$ & & & $\checkmark$ & $\checkmark$ & & $\checkmark$ & & \\
\hline $\begin{array}{l}\text { Kopi } \\
\text { Aksara }\end{array}$ & 1 & $\checkmark$ & & $\checkmark$ & 1 & $\checkmark$ & & $\checkmark$ & \\
\hline $\begin{array}{l}\text { Lutie } \\
\text { Coffee }\end{array}$ & $\checkmark$ & & & $\checkmark$ & & $\checkmark$ & & $\checkmark$ & \\
\hline Opposite & & $\checkmark$ & & $\checkmark$ & & $\checkmark$ & & $\checkmark$ & \\
\hline $\begin{array}{l}\text { Our } \\
\text { Coffee }\end{array}$ & & $\checkmark$ & & $\checkmark$ & & $\checkmark$ & & $\checkmark$ & \\
\hline Signatura & $\checkmark$ & & & $\checkmark$ & $\checkmark$ & & & $\checkmark$ & \\
\hline $\begin{array}{l}\text { Vein } \\
\text { Coffee }\end{array}$ & $\checkmark$ & & $\checkmark$ & & $\checkmark$ & & & & $\checkmark$ \\
\hline $\begin{array}{l}\text { Warung } \\
\text { Tubruk }\end{array}$ & $\checkmark$ & & & $\checkmark$ & & $\checkmark$ & & $\checkmark$ & \\
\hline $\begin{array}{l}\text { Warunk } \\
\text { Upnormal } \\
\text { Gejayan }\end{array}$ & $\checkmark$ & & & $\checkmark$ & $\checkmark$ & & & $\checkmark$ & \\
\hline $\begin{array}{l}\text { Warunk } \\
\text { Upnormal } \\
\text { Jakal }\end{array}$ & $\checkmark$ & & $\checkmark$ & & & $\checkmark$ & & $\checkmark$ & \\
\hline
\end{tabular}

Tabel 2. Tipe dalam Tipologi Berdasarkan Aktivitas

\begin{tabular}{|c|c|c|c|c|c|c|}
\hline \multirow[t]{2}{*}{ Karakteristik } & \multicolumn{6}{|c|}{ Tipe } \\
\hline & 1 & 2 & 3 & 4 & 5 & 6 \\
\hline $\begin{array}{l}\text { Sistem } \\
\text { Aktivitas }\end{array}$ & Sosial & Edukasi & Edukasi & Edukasi & Edukasi & Edukasi \\
\hline Jenis Tujuan & $\begin{array}{l}\text { In- } \\
\text { between }\end{array}$ & Utama & Utama & $\begin{array}{l}\text { In- } \\
\text { between }\end{array}$ & $\begin{array}{l}\text { In- } \\
\text { between }\end{array}$ & $\begin{array}{l}\text { In- } \\
\text { between }\end{array}$ \\
\hline $\begin{array}{l}\text { Durasi } \\
\text { Kunjungan }\end{array}$ & 3-4 jam & 1-2 jam & 3-4 jam & $1-2 \mathrm{jam}$ & $1-2 \mathrm{jam}$ & 3-4 jam \\
\hline $\begin{array}{l}\text { Preferensi } \\
\text { Waktu }\end{array}$ & $\begin{array}{l}18.00- \\
21.00\end{array}$ & $\begin{array}{l}21.00- \\
24.00\end{array}$ & $\begin{array}{l}18.00- \\
21.00\end{array}$ & $\begin{array}{l}16.00- \\
18.00\end{array}$ & $\begin{array}{l}18.00- \\
21.00\end{array}$ & $\begin{array}{l}18.00- \\
21.00\end{array}$ \\
\hline
\end{tabular}

Sumber: Olahan Peneliti, 2019

Dari pembagian tipe tersebut dapat dilihat bahwa masing-masing tipe memiliki perbedaan karakteristik tersendiri. Perbedaan yang paling terlihat ada pada Tipe 1 dibanding tipe lainnya dengan sistem aktivitas sosial sedangkan tipe lain memiliki sistem aktivitas edukasi. Hal ini salah satunya disebabkan oleh minimnya fasilitas yang tersedia pada kafe di Tipe 1 sehingga lebih mendukung untuk berinteraksi, sedangkan kafe lain memiliki fasilitas yang mendukung untuk aktivitas edukasi dengan keberadaan koneksi internet nirkabel dan banyaknya stopkontak. Pada Tipe 2 hingga Tipe 6 dengan sistem aktivitas edukasi, dikategorikan sebagai tipe kafe yang mendukung aktivitas co-working space terkait dengan 
sistem aktivitas yang dilakukan. Meskipun memiliki sistem aktivitas sama, terdapat perbedaan pada jenis tujuan, durasi kunjungan, dan preferensi waktu kunjungan masingmasing tipe.

Tabel 3. Tipologi Kafe Berdasarkan Aktivitas

\begin{tabular}{llllll}
\hline Tipe 1 & Tipe 2 & Tipe 3 & Tipe 4 & Tipe 5 & Tipe 6 \\
\hline Kopi Aksara, & Eastern & Warunk & Curio & Kronology, & Antologi, Couvee, \\
Opposite, Our & Kopi TM & Upnormal & Espresso, & Signatura, Warunk & Lutie, \\
Coffee & & Jakal & Vein Coffee & $\begin{array}{l}\text { Upnormal Gejayan } \\
\text { Tubruk }\end{array}$ & \\
& & & & &
\end{tabular}

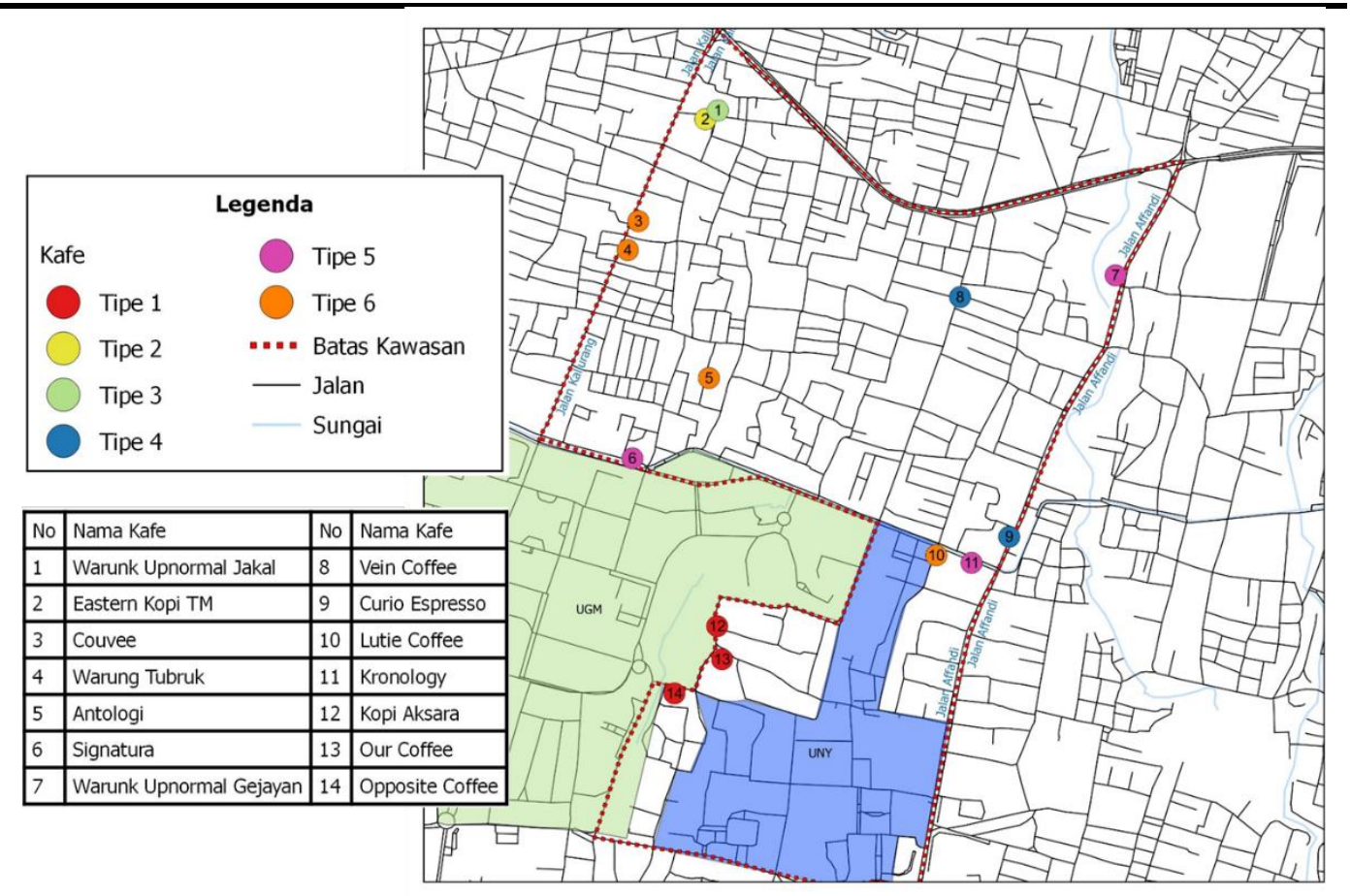

Sumber: Olahan Peneliti, 2019

\section{Gambar 4. Peta Tipologi Kafe Berdasarkan Aktivitas}

Tipologi berdasarkan aktivitas pada Gambar 4 menandakan bahwa terdapat kaitan antara penggunaan ruang kafe (sebagai third place atau co-working space) dengan lokasi secara spasial. Dilihat secara spasial, kafe yang digunakan sebagai co-working space memiliki kecenderungan untuk berada di sekitar distrik hunian dan indekos mahasiswa. Hal ini menandakan bahwa kafe di bagian utara kawasan memiliki tujuan pembangunan untuk memenuhi kebutuhan sistem aktivitas edukasi atau pendidikan. Sedangkan kafe yang berada di dekat kawasan selatan (kawasan dekat kampus) memiliki tujuan pembangunan untuk memenuhi kebutuhan sistem aktivitas sosial mahasiswa, dengan keterjangkauannya dari lokasi kampus, harga yang sesuai, dan kesederhanaan fasilitas yang dimiliki oleh kafe tersebut.

Analisis crosstab yang dilakukan pada bagian tipologi kafe berdasarkan karakter pengunjung menunjukan kecenderungan masing-masing sub-variabel tiap kafe yang kemudian diterjemahkan sebagai karakteristik tiap kafe berdasarkan aktivitas dalam Tabel 4. 
Tabel 4. Karakteristik Berdasarkan Karakter Pengunjung Tiap Kafe

\begin{tabular}{|c|c|c|c|c|c|}
\hline \multirow[t]{3}{*}{ Kafe } & \multirow{2}{*}{\multicolumn{2}{|c|}{$\begin{array}{c}\text { Rentang Usia } \\
\text { Pengunjung }\end{array}$}} & \multirow{2}{*}{\multicolumn{3}{|c|}{ Domisili Pengunjung }} \\
\hline & & & & & \\
\hline & $\begin{array}{l}18-20 \\
\text { tahun }\end{array}$ & $\begin{array}{l}21-23 \\
\text { tahun }\end{array}$ & $\begin{array}{l}\text { Depok, } \\
\text { Sleman }\end{array}$ & $\begin{array}{l}\text { Mlati, } \\
\text { Sleman }\end{array}$ & $\begin{array}{c}\text { Kecamatan } \\
\text { Lain di Sleman }\end{array}$ \\
\hline Antologi & & $\checkmark$ & & $\checkmark$ & \\
\hline Couvee & & $\checkmark$ & $\checkmark$ & & \\
\hline Curio Espresso & & $\checkmark$ & & $\checkmark$ & \\
\hline Eastern Kopi TM & $\checkmark$ & & & & $\checkmark$ \\
\hline Kopi Aksara & & $\checkmark$ & $\checkmark$ & & \\
\hline Kronology & $\checkmark$ & & $\checkmark$ & & \\
\hline Lutie Coffee & $\checkmark$ & & & $\checkmark$ & \\
\hline Opposite & & $\checkmark$ & $\checkmark$ & & \\
\hline Our Coffee & & $\checkmark$ & & & $\checkmark$ \\
\hline Signatura & & $\checkmark$ & & & $\checkmark$ \\
\hline Vein Coffee & & $\checkmark$ & & $\checkmark$ & \\
\hline Warung Tubruk & & $\checkmark$ & & $\checkmark$ & \\
\hline Warunk Upnormal & & $\checkmark$ & $\checkmark$ & & \\
\hline Gejayan & & & & & \\
\hline Warunk Upnormal Jakal & & $\checkmark$ & & $\checkmark$ & \\
\hline
\end{tabular}

Sumber: Olahan Peneliti, 2019

Dominasi yang terjadi dalam rentang usia dan jenis pekerjaan responden penelitian memperlihatkan adanya hubungan antara lokasi spasial dengan pasar pengunjung kafe sebagai third place di Kawasan Karangwuni dan sekitarnya. Rentang usia dominan 21-23 tahun dengan jenis pekerjaan dominan mahasiswa menandakan bahwa kafe di Kawasan Karangwuni dan sekitarnya memiliki dominasi pengguna yakni mahasiswa dari kampus yang berdekatan dengan lokasi ini, yakni Universitas Gadjah Mada dan Universitas Negeri Yogyakarta. Hal ini tidak menutup kemungkinan penggunaan dari mahasiswa kampus lain, ditandai dengan adanya pengunjung kafe yang memiliki domisili tempat tinggal dari kecamatan di luar Kecamantan Depok dan Kecamatan Mlati. Temuan ini menandakan bahwa kafe sebagai third place di Kawasan Karangwuni dan sekitarnya tidak terbatas pada masyarakat yang tinggal di sekitar lokasi, dilihat dari variasi domisili pengunjungnya. Karakteristik yang terbentuk kemudian dibandingkan dan diterjemahkan menjadi tipe dalam tipologi berdasarkan aktivitas pada Tabel 5 .

Tabel 5. Tipe dalam Tipologi Berdasarkan Karakter Pengunjung

\begin{tabular}{|c|c|c|c|c|c|c|}
\hline \multirow[t]{2}{*}{ Karakteristik } & \multicolumn{6}{|c|}{ Tipe } \\
\hline & 1 & 2 & 3 & 4 & 5 & 6 \\
\hline Rentang Usia & $18-20$ & $18-20$ & $18-20$ & $21-23$ & $21-23$ & $21-23$ \\
\hline Pengunjung & tahun & tahun & tahun & tahun & tahun & tahun \\
\hline Jenis & Mahasiswa & Mahasiswa & Mahasiswa & Mahasiswa & Mahasiswa & Mahasiswa \\
\hline \multicolumn{7}{|l|}{ Pekerjaan } \\
\hline \multicolumn{7}{|l|}{ Pengunjung } \\
\hline Domisili & Depok, & Mlati, & Kecamatan & Depok, & Mlati, & Kecamatan \\
\hline Pengunjung & Sleman & Sleman & Lain di & Sleman & Sleman & Lain di \\
\hline & & & Sleman & & & Sleman \\
\hline
\end{tabular}

Sumber: Olahan Peneliti, 2019 
Pada pembagian tipe dapat terlihat perbedaan berdasarkan rentang usia yang sama. Meskipun hanya terbagi menjadi dua rentang usia yakni 18-20 tahun dan 21-23 tahun, namun perbedaan pada domisili memicu pembagian tipe pada tipologi menjadi 6 bagian. Domisili pada tipologi ini memiliki pola yakni berdomisi di Depok, Mlati, dan Kecamatan Lain di Kabupaten Sleman sehingga dapat memunculkan 3 tipe untuk masing-masing rentang usia. Pengunjung yang menjadikan kafe sebagai tujuan in-between menambah variasi domisili tempat tinggal pengunjung pada kafe tersebut.

Tabel 6. Tipologi Kafe Berdasarkan Karakter Pengunjung

\begin{tabular}{|c|c|c|c|c|c|}
\hline Tipe 1 & Tipe 2 & Tipe 3 & Tipe 4 & Tipe 5 & Tipe 6 \\
\hline Kronology & $\begin{array}{l}\text { Lutie } \\
\text { Coffee }\end{array}$ & $\begin{array}{l}\text { Eastern } \\
\text { Kopi } \\
\text { TM }\end{array}$ & $\begin{array}{l}\text { Couvee, } \\
\text { Aksara, Opposite, } \\
\text { Warunk Upnormal } \\
\text { Gejayan }\end{array}$ & $\begin{array}{lr}\text { Antologi, } & \text { Curio } \\
\text { Espresso, Vein Coffee, } \\
\text { Warung } & \text { Tubruk, } \\
\text { Warunk } & \text { Upnormal } \\
\text { Jakal } & \end{array}$ & $\begin{array}{l}\text { Our Coffee, } \\
\text { Signatura }\end{array}$ \\
\hline
\end{tabular}

Sumber: Olahan Peneliti, 2019

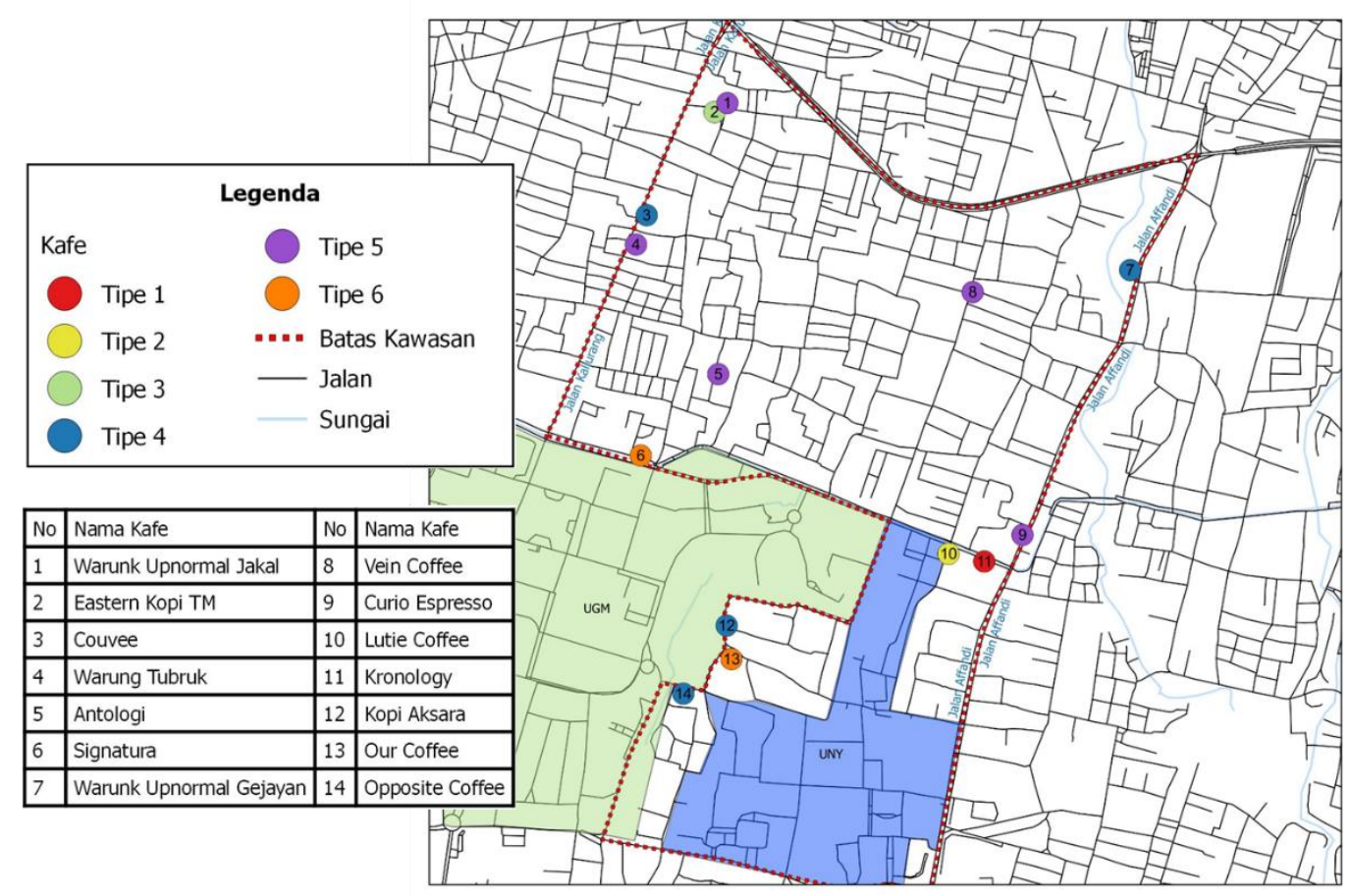

Sumber: Olahan Peneliti, 2019

\section{Gambar 5. Peta Tipologi Kafe Berdasarkan Karakter Pengunjung}

Peta pada Gambar 5 menunjukkan tidak terjadinya pengelompokan secara spasial pada masing-masing tipe. Namun dapat dilihat karakteristik kafe pada Tipe 5 yang cenderung berada di dalam lingkungan permukiman. Selain itu terjadi pula fenomena seperti dalam tipologi sebelumnya, yakni kafe yang secara spasial memiliki lokasi berdekatan, belum tentu memiliki kesamaan tipe. Secara spasial lokasi kafe tidak mempengaruhi rentang usia pengunjung tiap kafe sehingga tidak ada hubungan antara lokasi secara spasial dengan karakteristik pengunjung. 
Karakteristik pengunjung pengguna kafe di Kawasan Karangwuni dan sekitarnya menunjukan bahwa dominasi dari pengunjung kafe merupakan mahasiswa. Hal ini menandakan bahwa mahasiswa masih memiliki kewajiban menjalankan seluruh proses studinya di dalam second place yakni kampus. Adanya second place bagi mahasiswa menandakan pergeseran dari third place menjadi co-working space belum sepenuhnya terjadi, namun menandakan bahwa ruang kafe di Kawasan Karangwuni dan sekitarnya sudah dapat memenuhi kriteria pembentukan co-working space. Dapat disimpulkan bahwa ruang kafe di Kawasan Karangwuni dan sekitarnya masih tergolong dalam third place, namun penggunaan secara formal di dalam ruang informal kafe dapat menggolongkan bahwa ruang third place yang ada sudah dapat dikategorikan sebagai penggunaan ruang third place sebagai co-working space, bergantung pada latar belakang pengguna ruangnya (masih memiliki second place atau tidak).

Realita yang terjadi di lapangan, hanya kafe Antologi yang mengadopsi konsep coworking space dengan menyewakan ruang kerja untuk sebagian lahannya. Fenomena yang terjadi di lapangan adalah bentuk kafe sebagai third place di Kawasan Karangwuni dan sekitarnya mayoritas mulai bergeser penggunaannya menjadi sebagai co-working space karena suasana dan fasilitas mendukung untuk aktivitas tersebut. Di samping itu, keberadaan ruang kafe sebagai third place sudah merupakan kebutuhan masyarakat sebagai ruang in-between di antara aktivitas sehari-hari. Hal ini menandakan bahwa kafe sebagai third place secara spasial sebaiknya berada di sekitar tempat beristirahat maupun tempat bekerja karena berkaitan dengan tujuannya sebagai tempat penghilang rasa stres, keterasingan, maupun rasa bosan. Terlebih apabila kafe sebagai third place berkembang menjadi ruang yang digunakan untuk aktivitas seperti dalam co-working space yang menandakan bahwa keberadaan kafe berkaitan dengan produktivitas penggunanya. Dapat disimpulkan bahwa kafe, baik sebagai third place maupun co-working space, perlu dikembangkan secara spasial di antara tempat beristirahat maupun tempat bekerja karena akan mempengaruhi penggunanya, baik sebagai retensi dari aktivitas keseharian maupun sebagai ruang produktif pendukung pekerjaan. Fenomena yang terjadi di lapangan berupa ruang kafe yang digunakan sebagai co-working space perlu dibahas lebih lanjut dalam penelitian lain.

Pergeseran dari third place menjadi co-working space menandakan terjadinya pergeseran dari place menjadi space. Perbedaan antara space dan place adalah adanya nilai yang dapat membedakan pengalaman individu di dalam ruang (Vanclay et al., 2009). Hal ini menandakan bahwa terjadi hilangnya nilai yang dimiliki dalam ruang kafe sehingga third place dapat berubah menjadi co-working space. Pergeseran yang terjadi ada dalam hilangnya keseluruhan sifat informal yang dimiliki oleh third place karena dikombinasikan dengan sifat formal dari kegiatan produktif atau fungsional yang dilakukan dalam co-working space.

Kafe di Kawasan Karangwuni dan sekitarnya berkembang setiap tahunnya dengan pola yang acak, namun terdapat karakteristik spasial dalam perkembangannya tiap tahun. Dalam hal ini, kafe semakin lama semakin memperhatikan aksesibilitas dan setting ruang bagi pengunjung kafe sehingga dapat menimbulkan kenyamanan pagi orang yang datang. Sedangkan apabila hanya dilihat diantara tahun 2016-2018, pertumbuhan secara spasialnya dapat dilihat dalam peta pada Gambar 6. Dapat dilihat pada peta bahwa pertumbuhan yang terjadi pada kafe tidak memiliki pola. Sedangkan untuk melihat hubungan antara pertumbuhan kafe dengan tipologi yang terbentuk, dapat dilihat hubungan antara Gambar 6 dengan Tabel 7. 
Tabel 7. Hubungan Tahun Pembukaan Kafe dengan Tipologi

\begin{tabular}{lccc}
\hline Kafe & Tahun & \multicolumn{2}{c}{ Tipologi } \\
& & Kktivitas & Karakter Pengunjung \\
\hline Antologi & 2017 & 6 & 5 \\
Couvee & 2017 & 6 & 5 \\
Curio Espresso & 2018 & 4 & 3 \\
Eastern Kopi TM & 2016 & 2 & 4 \\
Kopi Aksara & 2017 & 1 & 1 \\
Kronology & 2017 & 5 & 2 \\
Lutie Coffee & 2018 & 6 & 4 \\
Opposite & 2017 & 1 & 6 \\
Our Coffee & 2018 & 1 & 6 \\
Signatura & 2018 & 5 & 5 \\
Vein Coffee & 2018 & 4 & 4 \\
Warung Tubruk & 2017 & 6 & 5 \\
Warunk Upnormal Gejayan & 2018 & 5 & 4 \\
Warunk Upnormal Jakal & 2018 & 3 & 5 \\
\hline
\end{tabular}

Sumber: Olahan Peneliti, 2019

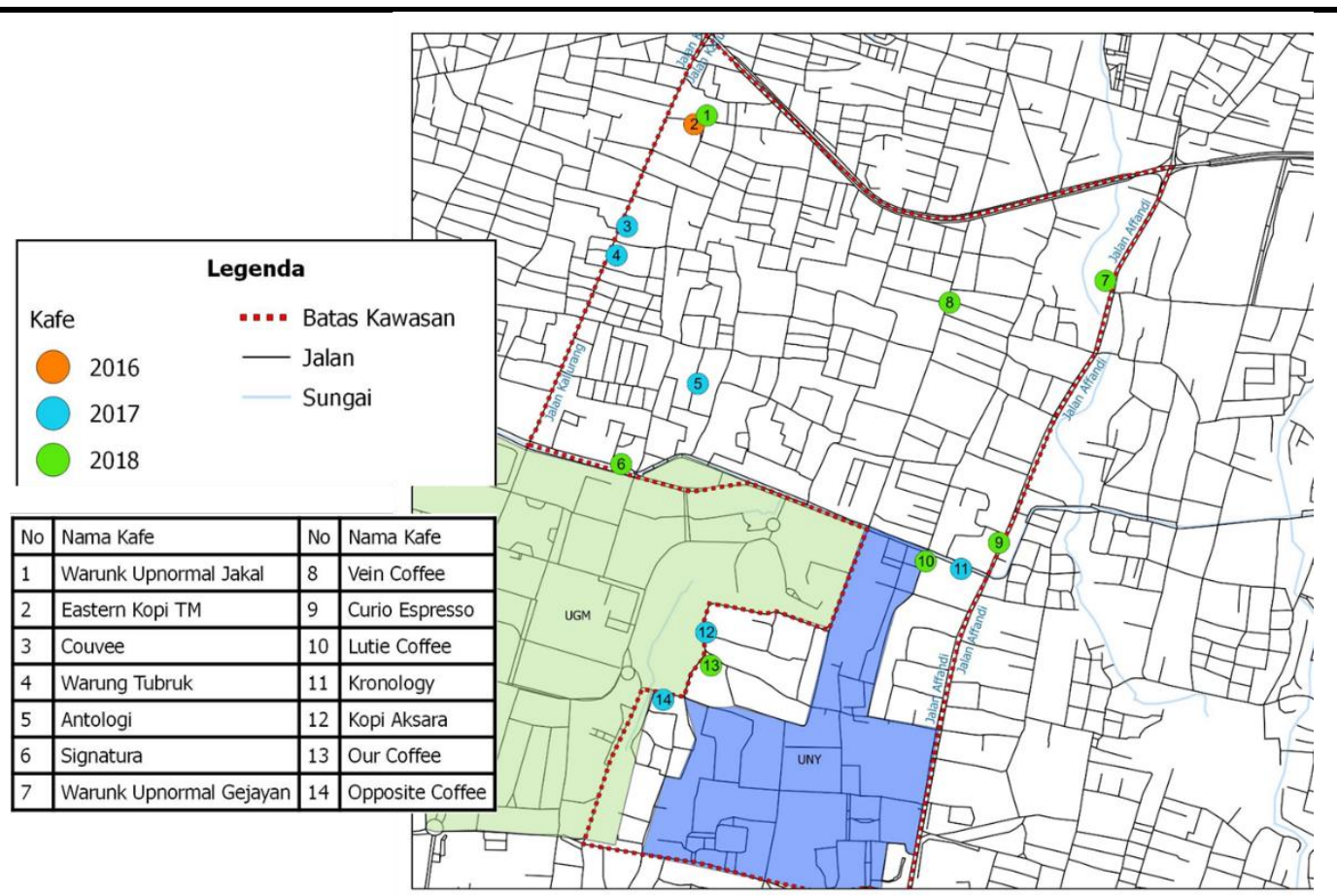

Sumber: Olahan Peneliti, 2019

Gambar 6. Perkembangan Spasial Kafe sebagai Third Place Tahun 2016-2018

Faktor pembentukan tipologi berhubungan erat dengan alasan pengunjung dalam mengunjungi kafe. Dari kuesioner yang telah dilakukan pengkodean, didapatkan 9 alasan pengunjung lebih memilih menggunakan kafe di Kawasan Karangwuni dan sekitarnya. Alasan tersebut yakni: suasana ruang kafe yang nyaman; pilihan menu makanan dan 
minuman yang enak; fasilitas yang tersedia pada kafe untuk mendukung aktivitas; lokasi yang terjangkau; familiar dengan barista maupun pemilik kafe; harga yang terjangkau; parkir yang luas; jam buka kafe; dan pemenuhan janji bertemu dengan orang lain.

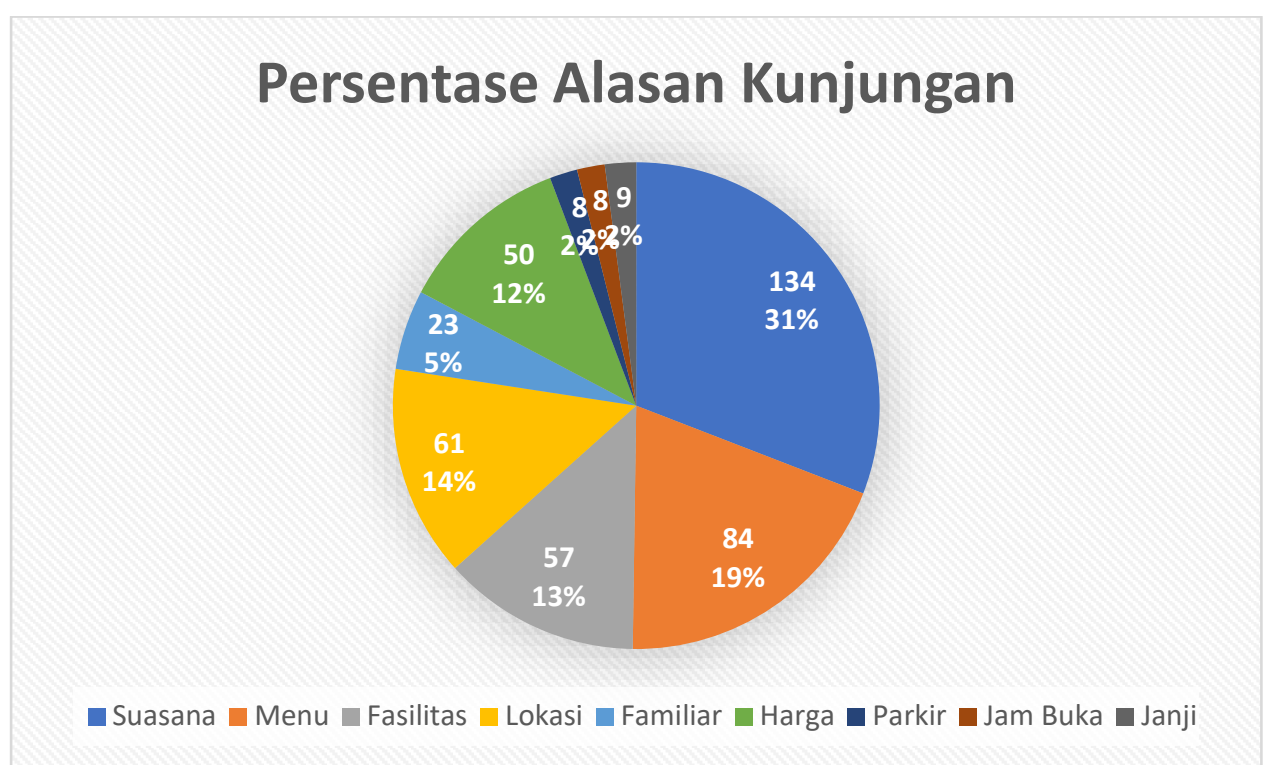

Sumber: Olahan Peneliti, 2019

\section{Gambar 7. Grafik Persentase Alasan Kunjungan}

Dari 248 responden dengan metode pertanyaan terbuka, setelah dilakukan pengkodean terdapat 434 jawaban dalam pertanyaan alasan mengunjungi kafe. Rincian untuk jawaban ini ada dalam Gambar 7. Hasil analisis menunjukkan bahwa alasan yang paling banyak dipilih yakni suasana ruang kafe yang nyaman. Hasil dari pengkodean yang dilakukan menunjukkan bahwa terdapat beberapa faktor yang berhubungan dengan setting ruang dalam pembentukan ruang kafe, yakni suasana ruang, fasilitas yang tersedia, lokasi yang terjangkau, parkir luas, dan jam buka kafe.

Hasil penelitian menunjukan adanya hubungan antara penelitian ini dengan penelitian yang pernah dilakukan sebelumnya bahwa pembentukan suatu kafe, aktivitas yang biasa dilakukan, dan pemanfaatan waktu luang akan turut mempengaruhi karakteristik third place yang terbentuk pada kafe. Durasi dan jenis pemanfaatan waktu luang dapat turut mempengaruhi variasi tipe-tipe kafe berdasarkan aktivitas yang terbentuk berkaitan dengan sistem aktivitas, tujuan, durasi kunjungan, dan preferensi waktu kunjungan ketika berkunjung ke kafe, hal ini sejalan dengan penelitian oleh Fatmawati (2015). Selain itu, kecenderungan pemanfaatan kafe sebagai tempat untuk melakukan pekerjaan dapat turut mempengaruhi karakterstik pembentukan kafe dan faktor-faktor pembentukan kafe di perkotaan Yogyakarta yang dibahas dalam penelitian Anggrianita (2016). Oleh karena itu, penelitian kedepan dapat dikembangkan dengan mengamati secara mendalam perkembangan atau pergeseran orientasi pemanfaatan ruang third place menjadi co-working space.

\section{KESIMPULAN}

Karakteristik third place pada kafe di Kawasan Karangwuni dan sekitarnya sesuai dengan karakteristik third place yang dikemukakan oleh Oldenburg (1989). Fakta di lapangan memperlihatkan bahwa terdapat beberapa kondisi yang mulai menggeser karakteristik yang 
ada, seperti munculnya perubahan dalam pemanfaatan ruang kafe, di antaranya perubahan bentuk interaksi dan aktivitas yang dilakukan pada kafe sebagai third place.

Perubahan bentuk interaksi yang terjadi pada kafe sebagai third place dipengaruhi oleh digitalisasi dalam berbagai sektor kehidupan dan dukungan teknologi dalam interaksi manusia yang memungkinkan interaksi dilakukan secara tidak langsung. Kemudahan yang ada turut memberi dampak pada kafe sebagai third place di Kawasan Karangwuni dan sekitarnya dengan mulai bergesernya bentuk interaksi yang terjadi-dari interaksi secara langsung menjadi interaksi secara tidak langsung.

Kemudahan akibat digitalisasi tidak hanya mempengaruhi bentuk interaksi, namun turut mengubah aktivitas yang dilakukan pada kafe sebagai third place. Digitalisasi turut mendukung adanya pekerjaan manusia yang dapat dikerjakan dari jarak jauh (remote) dan dapat mempengaruhi penggunaan kafe sebagai third place. Sistem aktivitas yang mendominasi dilakukan pada kafe sebagai third place di Kawasan Karangwuni dan sekitarnya yakni sistem aktivitas edukasi yang merupakan aktivitas formal berkaitan dengan pendidikan dengan dominasi responden dalam penelitian ini yang merupakan mahasiswa. Pergeseran ini terjadi pada beberapa kafe yang mengalami pergeseran bentuk aktivitas sehingga dapat dikatakan merupakan kafe dengan penggunaan sebagai co-working space. Adanya second place bagi mahasiswa yakni kampus menjadikan hanya bergesernya penggunaan ruang pada kafe di kawasan Karangwuni dan sekitanya menjadi co-working space, tidak bergeser sepenuhnya namun hanya menandakan bahwa kafe sudah mendukung untuk digunakan sebagai co-working space dengan dukungan fasilitas yang disediakan. Fasilitas ini di antaranya keberadaan koneksi internet nirkabel, jumlah stopkontak yang banyak, dan suasana ruang mendukung.

Tipologi pada kafe di Kawasan Karangwuni dan sekitarnya menunjukkan adanya perbedaan tipe, meskipun terjadi kesamaan karakteristik utama. Perbedaan latar belakang pengunjung kafe merupakan salah satu pengaruh variasi tipe yang ada. Variasi tipologi secara spasial memiliki kesamaan karakteristik, seperti kencenderungan mengelompok dan kecenderungan lokasi kafe. Selain itu dilihat dari preferensi waktu kunjungan, pengunjung memiliki kecenderungan waktu pada malam hari, bahkan hingga larut malam yang berpotensi mengganggu lingkungan sekitar kafe sebagai third place dengan kebisingan suara. Pemerintah dapat melakukan tindakan preventif dari kemungkinan dampak yang ditimbulkan dengan penegasan aturan operasional kafe sehingga dapat menciptakan lingkungan kondusif bagi masyarakat di sekitar lokasi kafe. Sedangkan hasil analisis pada perkembangan spasial pada kafe sebagai third place di Kawasan Karangwuni dan sekitarnya menandakan bahwa tidak terdapat hubungan antara pertumbuhan kafe dengan tipologi yang terbentuk.

Tipologi berdasarkan aktivitas menandakan bahwa terdapat kaitan antara penggunaan ruang kafe (sebagai third place atau co-working space) dengan lokasi spasial. Kafe dengan penggunaan sebagai co-working space memiliki kecenderungan untuk berada di sekitar distrik hunian dan indekos mahasiswa. Hal ini menandakan bahwa kafe di sekitar kawasan tersebut dibangun dengan tujuan pembangunan untuk memenuhi kebutuhan sistem aktivitas edukasi atau pendidikan. Sedangkan kafe yang berada di dekat kampus (kawasan karangmalang) memiliki kecenderungan penggunaan sebagai third place yang menandakan tujuan pembangunannya untuk memenuhi kebutuhan sistem aktivitas sosial mahasiswa, dengan keterjangkauannya dari lokasi kampus dan kesederhanaan fasilitas yang disediakan.

Faktor pembentukan tipologi disebabkan oleh latar belakang pengunjung dalam mengunjungi kafe karena turut membentuk tipologi. Adanya karakteristik kafe yang mendukung aktivitas sesuai dengan keinginan pengunjung, menjadi salah satu kriteria dalam memilih kafe tujuan. Selain itu, latar belakang yang dimiliki pengunjung turut mempengaruhi pembentukan tipologi yang ada dengan karakter masing-masing pengunjung. Dari hasil analisis, alasan berkunjung paling utama yang mempengaruhi pembentukan tipologi adalah suasana ruang kafe nyaman bagi pengunjung. Selain itu 
beberapa alasan yang dimiliki pengunjung merupakan alasan yang berkaitan dengan setting ruang dalam pembentukan kafe yakni suasana ruang, fasilitas yang tersedia, lokasi yang terjangkau, parkir luas, dan jam buka kafe.. Setting ruang merupakan pembentukan ruang untuk mendukung aktivitas yang dilakukan penggunanya dan kenyamanan berdasar suasana ruang.

\section{DAFTAR PUSTAKA}

Anggrianita, S. (2016). Karakteristik Kafe di Perkotaan Yogyakarta, Studi Kasus Kawasan Seturan, Demangan, dan Prawirotaman. Universitas Gadjah Mada.

Brown, J. (2017). Curating the "Third Place"? Coworking and the mediation of creativity. 82(July 2016), 112126. https://doi.org/10.1016/j.geoforum.2017.04.006

Chapin, F. S. (1965). Urban Land Use Planning. University of Illinois Press.

Clifton, N., \& Crick, T. (2016). NEMODE Network+ 3K Open Call Final Report: New Economic Models for, and from, Co-Working. March 2016. https://doi.org/10.13140/RG.2.2.19181.38889

Fatmawati, A. (2015). Pemanfaatan Ruang untuk Waktu Luang di Kalangan Mahasiswa Universitas Gadjah Mada. Universitas Gadjah Mada.

Fauzi, A., Punia, I. N., \& Kamajaya, G. (2017). Tinjauan Gaya Hidup Anak Muda Di Kota Denpasar. Jurnal Ilmiah Sosiologi (SOROT), 1(1). https://ojs.unud.ac.id/index.php/sorot/article/view/29665

Francis D.K Ching. (1979). Architecture Form, Space, and Order. Van Nostrand Reinhold Company.

Mehta, V., \& Bosson, J. K. (2010). Third places and the social life of streets. 42(6). https://doi.org/10.1177/0013916509344677

Merkel, J. (2015). Coworking in the City. https://doi.org/10.1057/ip.2011.10

Nenonen, S., \& Kojo, I. (2016). Typologies for co-working spaces in Finland - what and how? Facilities, 34(5/6), 302-313. https://doi.org/http://dx.doi.org/10.1108/MRR-09-2015-0216

Oldenburg, R. (1989). The Great Good Place. In The Great Good Place (Vol. 2).

Passmore, A., \& French, D. (2001). Development and administration of a measure to assess adolescents' participation in leisure activities. 36(141).

Pozos-Brewer, R. (2015). Coffee Shops : Exploring Urban Sociability and Social Class in the Intersection of Public and Private Space. Farha Ghannam.

Stumpf, C. (2013). Creativity \& Space: The Power of Ba in Coworking Spaces.

Suharjanto, G. (2017). Keterkaitan Tipologi dengan Fungsi dan Bentuk: Studi Kasus Bangunan Masjid. ComTech: Computer, Mathematics and Engineering Applications, 4(2), 975-982. https://doi.org/10.21512/comtech.v4i2.2539

Vanclay, F., Higgins, M., \& Blackshaw, A. (2009). Making sense of place: Exploring concepts and expressions of place through different senses and lenses. In Geographical Education (Vol. 22, Issue April/May).

Yusuf, A. M. (2016). Metode Penelitian Kuantitatif, Kualitatif \& Penelitian Gabungan. Prenada Media. 